\title{
The Goat Technopreneurial Learning Project (TLP) of the Nueva Vizcaya State University
}

\author{
Dr. Angelito L. Lacadin \\ Nueva Vizcaya State University, Bayombong, Nueva Vizcaya, Philippines
}

\begin{abstract}
This development project was conducted to increase enrollment and enhance the entrepreneurial capability and employability of AFNR students and graduates of SUCs in Region II and Region III through an alliance of learning of CLARRDEC and CVARRD. Specifically, it aimed to: 1) foster an intra and inter-regional/institutional alliance of learning in CLARRDEC and CVARRD; 2) enrich/develop and implement industry-responsive and harmonized curricular and short-term training; 3) enhance students' learning environment through upgrading of facilities and establishment of income generating projects; 4) improve the technical and entrepreneurial skills of AFNR students and graduates towards gainful employment and enterprise development; 5) establish linkages/partnership with the public-private sector; and 6) institutionalize the consortium alliance, enriched curriculum, income generating projects and public-private sector partnership to ensure sustainability of the initiated projects. Based on the results of this project, the following are recommended: shift from production of slaughter goats to breeder goats, upgrading of breeder stocks; shift from complete confinement to semi-confinement method; pasture development by planting legume trees along fences and planting of improve grasses and legumes; linkages with government agencies, goat and sheep producers' associations and entrepreneurs; conduct of the Goat Production and Entrepreneurship Training; and impact assessment study.
\end{abstract}

Keywords: development project, industry-responsive, consortium, entrepreneurial

\section{Introduction}

Enrollment in agriculture, forestry and natural resources (AFNR) courses in State Universities and Colleges (SUCs) in the whole country has dwindled. This has been the trend not only in the Philippines but worldwide due to decrease in job opportunities for AFNR graduates and the decreased contribution of AFNR to the Gross National Product of the country for the last three decades.

It can be observed as well that the agriculture and agriculture related programs in the SUCs had become variable in academic quality, with insufficient attention on gaining practical skills towards entrepreneurship and often lacked relevance to industry needs. Given the situation, there is a need to strengthen institutional capability for quality education that will require improved professional capacities, responsive curriculum and upgrade present facilities, hoping that this would reverse the downtrend in enrollment and provide opportunities for more students to gain practical knowledge and skills towards entrepreneurship and gainful employment. The situation was addressed immediately and collectively. This included finding solutions and innovations to increase enrollment and employability and creating a generation of entrepreneurs, so as not to threaten the very existence of these SUCs. Building an intra and interregional/institutional alliance is a novel approach to collectively respond to the challenges in the spirit of partnership, complementation, cooperation and collaboration.

The consortium alliance of Central Luzon Agriculture and Resources Research and Development Consortium (CLARRDEC) and Cagayan Valley Agriculture and Resources Research and Development (CVARRD) exercised resource complementation, sharing of valuable information, experiences and best practices. The concerted effort capitalized on member-SUCs expertise and comparative ad-vantage in academics, science research, technology development, and testing, assessment, and development of products. The consortia proceeded in a unified effort of effectively utilizing resources, sciencebased technologies, multitude of progressive interventions, taking advantage of enhancing curriculum, building capacities, establishing income generating projects (IGPs), upgrading facilities, and building public-private sector partnership with the view of institutionalizing these efforts to ensure continuity and achieve the project goals and objectives.

The Nueva Vizcaya State University Small Ruminant IGE (Income Generating Enterprise) was a common venue for laboratory classes for the Animal Science and Animal Production subjects offered by the College of Agriculture. Thus, the establishment of the Goat Technopreneurial Learning Project was crucial to the University's performance of its vision and mission as Center of Excellence.

Generally, this development project was conducted to increase enrollment and enhance the entrepreneurial capability and employability of AFNR students and graduates of SUCs in Region II and Region III through an alliance of learning of CLARRDEC and CVARRD. Specifically, it aimed to: 1) foster an intra and interregional/institutional alliance of learning in CLARRDEC and CVARRD; 2) enrich/develop and implement industryresponsive and harmonized curricular and short-term training courses on AFNR; 3) enhance students' learning environment through upgrading of facilities and establishment of income generating projects; 4) improve the technical and entrepreneurial skills of AFNR students and graduates towards gainful employment and enterprise development; 5) establish linkages/partnership with the public-private sector; and 6) institutionalize the consortium alliance, enriched curriculum, and public-private sector partnership to ensure continuity of the project efforts. 


\section{International Journal of Science and Research (IJSR) ISSN (Online): 2319-7064 \\ Index Copernicus Value (2013): 6.14 | Impact Factor (2015): 6.391}

\section{Methodology}

\subsection{Conceptual Framework}

The conceptual framework of the fundamental elements and components of the project is shown in Figure 1.

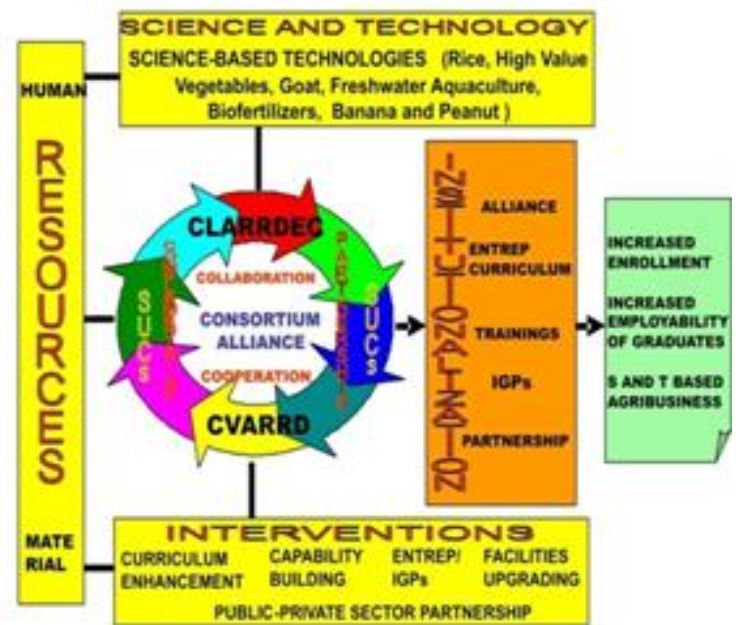

Figure 1: Conceptual framework of the fundamental elements and components of the project.

The utilization of resources, science and technology, and direction of interventions by the alliance of CLARRDEC and CVARRD enhanced the potential of institutionalization and meeting the project's goals of increasing the enrollment and employability of AFNR students and graduates of NVSU, as well as creating successful entrepreneurs of Science and Technology based agribusiness. Central to the implementation of the project was the intra and interregional/institutional alliance of CLARRDEC and CVARRD. Member SUCs shared knowledge and information, learned from each other's best practices and approached challenges together in an environment of partnership, complementation, cooperation and collaboration thru visitations and consultative meetings. The existing resources of SUCs, both human and physical, as well as the funding support from DOST/PCARRD were tapped in order to bring about development of science-based technology for goats as well as technologies on hybrid and aromatic rice, high value vegetables (tomato and onion), freshwater aquaculture, bio-fertilizers, peanut and banana which are other components under the consortium alliance.

This study was conducted mainly to establish a goat technopreneurial learning project (TLP) at NVSU. Other interventions included enhancing curriculum, building capacities, upgrading facilities, and building public-private sector partnership. Curriculum enhancement strengthened academic programs by integrating entrepreneurship with industry focus. Capacity building focused on faculty, staff, students and graduates development by providing them enriched curriculum design, R \& D support, upgraded facilities and educational training to hone their technical and managerial skills. Upgrading of facilities focused on improving the learning environment for NVSU which was beneficial in enticing more students to enroll.

The Goat TLP demonstrated the viability of science-based agricultural technology and served as training venue for students', graduates', and farmers' acquisition of technical and entrepreneurial skills necessary for starting their own businesses.

\section{Results and Discussion}

\section{Accomplishments}

\section{TLP Implementation}

The Goat TLP started implementing activities with the purchase of one full-blood Boer Buck, 25 native and upgraded does (Anglo-Nubian and Boer) and six kids which were sourced from three goat farms in Nueva Vizcaya and one farm in Isabela from January 20 to 23, 2010 for P80,000.00. The project produced 27 kids, bought on loan one Anglo-Nubian Buck and sold 16 goats. However, due to inclement weather and diseases, 14 heads died including the Anglo-Nubian Buck. As of May 31, 2011, there were 18 does, 4 buck and replacement bucks, and 8 kids valued at a total of P76,000.00 (Table 1).

Table 1: Inventory report from January 23, 2010 to May 31, 2011

\begin{tabular}{|c|r|r|r|r|r|r|r|r|}
\hline \multirow{2}{*}{ Classification } & \multicolumn{2}{|c|}{ Beg. Inventory } & $P$ & $M$ & $S$ & \multicolumn{2}{c|}{$U$} & \multicolumn{2}{|c|}{ End. Inventory } \\
\cline { 2 - 9 } & Qty & $P$ & Qty & Qty & Qty & Qty & Qty & $P$ \\
\hline Does & 14 & 38,000 & 0 & 0 & 6 & 5 & 13 & 40,000 \\
\hline Replacement Does & 7 & 20,000 & 0 & 0 & 2 & -3 & 2 & 6,000 \\
\hline Buck & 1 & 12,000 & 1 & 1 & 0 & 0 & 1 & 18,000 \\
\hline Replacement Buck & 0 & 0 & 0 & 0 & 1 & 2 & 1 & 3,000 \\
\hline Doeling & 5 & 5,000 & 0 & 3 & 1 & 2 & 3 & 3,000 \\
\hline Bucklings & 2 & 2,000 & 0 & 1 & 3 & 4 & 2 & 2,000 \\
\hline Buckkids & 0 & 0 & 14 & 3 & 0 & -5 & 6 & 3,000 \\
\hline Doekids & 0 & 0 & 13 & 6 & 0 & -5 & 2 & 1,000 \\
\hline Culled Does & 3 & 3,000 & 0 & 0 & 3 & 0 & 0 & 0 \\
\hline Total & 32 & 80,000 & 28 & 14 & 16 & 0 & 30 & 76,000 \\
\hline
\end{tabular}

Legend: P - produced or procured; $\mathrm{M}$ - mortality; $\mathrm{S}$ - sold

\section{Curriculum Enrichment}

Six curricular offerings of the College of Agriculture and College of Human Ecology were enhanced such as BSA, BAS-DVM, BSAB, DAT-BAT, BSHT and BSHM.
Entrepreneurship is part and parcel of these curricula and hands-on class activities were undertaken to enable the students to experience owning and managing their classroom enterprises. The TLP on Goat has been incorporated in the

\section{Volume 5 Issue 4, April 2016}




\section{International Journal of Science and Research (IJSR) \\ ISSN (Online): 2319-7064 \\ Index Copernicus Value (2013): 6.14 | Impact Factor (2015): 6.391}

syllabi as venue for laboratory activities in the different courses, and as a training ground for field practice, internship and on-the-job training for CA students.

\section{Training Design and Module Preparation}

Seven SUCs implementing TLPs on goat have prepared a common training module for Goat Production and Entrepreneurship. This has been used by the Goat TLP for the three trainings it had conducted and for future trainings to be conducted.

\section{Facilities Enhancement and Equipment Purchased}

NVSU fulfilled its commitment to share in funding this study (Goat TLP) by constructing the goat house costing P159,588.00 (P95,032.58 cash purchases and P64,555.42 non-cash expense) from its capital outlay in
2009. The fence surrounding the five-hectare forage area has been repaired from which one hectare has been planted with improve grasses, such as Napier (Pennisetum purpureum) and Guinea grass (Panicum maximum), at a cost of P63,370.00 from both the AFNR and NVSU funds. The water and electrical facilities, which were tapped on NVSU system, were enhanced from AFNR funds amounting to P9,850.60.

An old motorcycle of the University was re-paired and fabricated with sidecar to facilitate hauling of cut grasses especially to distant area adjacent to the project. Dial-type hanging scale, wheelbarrow and rakes were purchased. All in all, NVSU has spent P175,568.00 while P84,889.60 of AFNR were used for facilities enhancement (Table 2).

Table 2: Facilities enhancement and equipment purchased from January 1, 209 to May 31, 2011.

\begin{tabular}{|c|c|c|c|}
\hline \multirow{2}{*}{ Item } & \multicolumn{3}{|c|}{ Source and Amount (P) } \\
\cline { 2 - 4 } & AFNR Budget & SUC Counterpart & Total (P) \\
\hline Goat House & & $159,588.00$ & $159,588.00$ \\
\hline Fence \& Pasture & $49,660.00$ & $13,710.00$ & $63,370.00$ \\
\hline Water System & $13,268.60$ & 0 & $13,268.60$ \\
\hline Electrical System & $6,582,00$ & 0 & $6,582,00$ \\
\hline Tricycle & $11,879.00$ & 0 & $11,879.00$ \\
\hline Weighing Scale & $3,500.00$ & 0 & $3,500.00$ \\
\hline Wheelbarrow & 0 & $1,950.00$ & $1,950.00$ \\
\hline Rake & 0 & 320.00 & 320.00 \\
\hline Total & $\mathbf{8 4 , 8 8 9 . 6 0}$ & $\mathbf{1 7 5 , 5 6 8 . 0 0}$ & $\mathbf{2 6 0 , 4 5 7 . 6 0}$ \\
\hline
\end{tabular}

\section{Trainings Conducted}

The first training was conducted on March 5 \& 6, 2010 at the NVSU Dumlao Farmers Training Center (DFTC) and the AFNR Goat TLP. The training was designed for students and was announced three weeks in advance even in University Radio. Seventy-three students signed-in but 103 were actually registered and attended the said first training. The first batch was 99 students, 1 AFNR alumnus, 1 farmer/goat raiser, and 2 budding entrepreneurs are the participants. The proceedings for the training were finished.

A shortened training was conducted on March 23, 2010 to accommodate the request of the members of the LGU of Rosario, La Union. There was a briefing on the goat industry (including its prospects), lectures on goat production management practices, and a visit to the NVSU-AFNR Goat TLP. It was attended by 127 local government officials and employees of the said LGU.

The second training was conducted in May 7 \& 8, 2010 at the NVSU Dumlao Farmers Training Center (DFTC) and the AFNR Goat TLP. The training was designed for graduates of AFNR, farmers and entrepreneurs. It was announced over the University Radio Station 96.5 UFM for one week and thru the Municipal Agricultural Officers of Aritao, Bayombong, Bambang, and Solano. Members of the Abian-Abinganan Goat Raisers' Association and the Nueva Vizcaya Small Ruminant Raisers' Association were also informed about the said training. However, only 10 farmers and members of the said associations were able to participate due to their previous commitments related to the election that coincided during that time.

The third and last training was conducted specifically for the members of the two above-mentioned associations and for
AFNR graduates on August 12 \& 13, 2010. Forty clients were trained which include 23 AFNR alumni, 7 DA employees, 4 AFNR students, and 6 farmer-entrepreneurs involved in goat production.

After the last training, it was summed- up to have 308 trainees on the over-all. It is actually consisted of 125 AFNR students, 30 AFNR alumni, 135 LGU officers and employees, and 18 farmers, trainors and project staffs (Table 3).

Table 3: Trainings conducted and participants immersed from June 1, 2009 to May 31, 2011.

\begin{tabular}{|c|c|c|c|c|c|c|c|c|}
\hline \multirow{3}{*}{$\begin{array}{l}\text { Title and Date of } \\
\text { Training/Immersion }\end{array}$} & \multicolumn{8}{|c|}{ Number of Participants } \\
\hline & \multicolumn{2}{|c|}{$\begin{array}{l}\text { Faculty } \\
\text { \& Staff }\end{array}$} & \multicolumn{2}{|c|}{ Students } & \multicolumn{2}{|c|}{ Alumni } & \multicolumn{2}{|c|}{$\begin{array}{l}\text { Other } \\
\text { Clients }\end{array}$} \\
\hline & $T$ & $A$ & $T$ & $A$ & $T$ & $A$ & $T$ & $A$ \\
\hline $\begin{array}{l}\text { Goat Production } \\
\text { and } \\
\text { Entrepreneurship } \\
\text { Training }\end{array}$ & & & & & & & & \\
\hline March 5-6, 2010 & & 3 & & 99 & & 1 & & 3 \\
\hline March 23, 2010 & & 0 & & 0 & & 0 & & 108 \\
\hline May 7-8, 2010 & & 8 & & 22 & & 6 & & 18 \\
\hline $\begin{array}{l}\text { August 12-13, } \\
2010\end{array}$ & & 7 & & 4 & & 23 & & 6 \\
\hline Total & 3 & 18 & 40 & 125 & 30 & 30 & 38 & 135 \\
\hline $\begin{array}{l}\text { OJT, Practicum, } \\
\text { etc }\end{array}$ & $\mathbf{0}$ & $\mathbf{0}$ & 40 & 79 & $\mathbf{0}$ & $\mathbf{0}$ & $\mathbf{0}$ & $\mathbf{0}$ \\
\hline
\end{tabular}

\section{Immersion of Students, Alumni and Other Clients}

The project served as laboratory for students in conducting relevant activities in goat production and management. Seventy nine (79) students had undertaken Field Practice, 


\section{International Journal of Science and Research (IJSR) \\ ISSN (Online): 2319-7064 \\ Index Copernicus Value (2013): 6.14 | Impact Factor (2015): 6.391}

Occupational Internship Program (OIP), Practicum and Student Assistant-ship, and other goat management practices.

\section{Linkages/Partnerships}

The NVSU Goat TLP has established linkages with CLSUSRC and CVHILROS as sources of technical assistance forage seeds and other planting materials, and other resources in support to the project. The Office of the Provincial Veterinarian has also provided some of the veterinary medicines (vaccines, dewormers, etc.) used in the TLP. Linkages of the TLP manager with the AbianAbinganan Goat Raiser's Association, Inc. and the Nueva Vizcaya Small Ruminant Raisers' Association were strengthened with the conduct of the Goat Production and Entrepreneurship Training with some members of the two associations. Some LGUs of the province were tapped to recommend interested farmers and entrepreneurs on goat production (Table 4).

Table 4: Linkages of the project from June 1, 2009 to May 31, 2011

\begin{tabular}{|c|c|}
\hline Agency/Institution & Nature of Linkage \\
\hline $\begin{array}{l}\text { Cagayan Valley Hillyland Research Outreach Station } \\
\text { (CVHILROS) }\end{array}$ & $\begin{array}{l}\text { - Training and technical assistance } \\
\text { - Source of breeder, seeds \& forages }\end{array}$ \\
\hline CLSU - Small Ruminant Center & - Training and technical assistance \\
\hline NV Provincial Veterinary Office & - Source of free veterinary medicines \\
\hline Abian-Abinganan Goat Raisers Association & $\begin{array}{l}\text { - Partner in production training } \\
\text { - Source of industry information }\end{array}$ \\
\hline NV Small Ruminant Raisers Association & $\begin{array}{l}\text { - Partner in production training } \\
\text { - Source of industry information }\end{array}$ \\
\hline LGU of Rosario, La Union & - Client in goat production training \\
\hline $\begin{array}{l}\text { LGU of Aritao, Dupax del Sur, Dupax del Norte, } \\
\text { Bambang, Bayombong, Sta. Fe \& Quezon }\end{array}$ & - Partners in production training \\
\hline
\end{tabular}

\section{Summary and Recommendations}

\subsection{Summary}

The overall effect of the study on enrollment can be measured only indirectly after the effects of the intervening factors between the establishment of the TLP and enrollment in Agriculture, Forestry and Natural Resources are identified and quantified. However, the summary of findings and observations on the specific outputs of the NVSU Goat TLP are as follows:

1) The CVARRD and the CLARRDEC consortium alliance was established and functioned.

2) Six curricula were enriched with $120 \%$ accomplishment over target.

An entrepreneurial-based training manual was written by TLP Managers of seven SUCs implementing the establishment of goat TLPs, for a 100\% accomplishment.

3) NVSU was able to establish its Goat TLP for a $100 \%$ accomplishment.

4) The Project enhanced its 5 hectare facility was the university's counterpart, improved its forage area, and purchased facilities that supported the TLP for a $100 \%$ accomplishment.

5) The TLP conducted training of 125 students, 30 AFNR graduates and 153 other clients for a $280 \%$ accomplishment over target number.

6) It has forged linkages and partnerships with government agencies, goat and sheep organizations, and entrepreneurs for a $100 \%$ accomplishment.

7) It institutionalized the TLP by turning it over to the University Business Affairs Program for sustainability.

\subsection{Recommendations}

The NVSU Goat TLP was established primarily to serve as a venue for trainings and a showcase of viable technology in goat production and entrepreneurship. Thus, inherent in this is the capacity to generate income to sustain the project.
With the building and facilities, stock and management structure in place, the operational problem can be solved with the following:

1) Shifting from production of slaughter goats to breeder goats, thus continued upgrading of breeder stocks.

2) Shifting from complete confinement to semi-confinement method of production.

3) Continued forage area/pasture development by planting legume trees along fences and planting of improve forage grasses and legumes.

4) Continued linkages with government agencies, goat and sheep producers' associations and entrepreneurs.

5) Continued conduct of the Goat Production and Entrepreneurship Training.

6) Conduct of impact assessment study.

\section{References}

[1] CRUZ, E.M., A.P. SORIANO, M.C.DG. MADLAO, N.C. CABARAL, M.A.G. BELTRAN, S.C. BABERA, L.G.G. MANZANO, L.R. PAGATPATAN, J.N. NAYGA, R.C. SANSANO, M.C. HERNANDEZ, F.L. PORCIUNCULA, M.M.S. RECTO, P.J. RAFAEL, and G.Z. LAGGUI. 2011. Goat production and entrepreneurship training manual. CLSU, Science City of Munoz, Nueva Ecija: CLARRDEC, CVARRD, and PCARRD- DOST.

[2] PHILIPPINE COUNCIL FOR AGRICULTURE, FORESTRY AND NATURAL RESOURCES RESEARCH AND DEVELOPMENT. 2006. Philippine Recommends for Goat Farming. PCARRD, Los Baños, Laguna. 